\title{
日射が当たるガラス板表面温度の実用的測定法に関する実験的研究 EXPERIMENTAL STUDY ON PRACTICAL METHOD FOR MEASUREMENT OF SURFACE TEMPERATURE ON GLASS PLATE EXPOSED TO SOLAR RADIATION
}

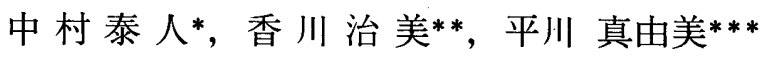 \\ Yasuto NAKAMURA, Harumi KAGAWA and Mayumi HIRAKAWA
}

\begin{abstract}
A practical method for the measurement of surface temperature on a glass plate exposed to solar radiation is proposed based on results of the field experiment. In the experiment surface temperature on the glass plate was measured by a T-type thermo-couple with a cover of adhesive transparent plastic tape, besides solar radiation on the glass plate was recorded simultaneously. The true value of surface temperature was measured by a thermo-graph. A regression line of the temperature difference between the true value and the value measured by the thermo-couple corresponding to solar radiation has been determined by using the experimental results.
\end{abstract}

Keywords : surface temperature, glass plate, solar radiation, measurement, thermo-couple, regression coefficient 表面温度、ガラス板、日射、測定、熱電対、回㷌係数

\section{1.はじめに}

日射が当たるガラス板の表面温度を正しく測ることは極めて困難 なため、関連文献は少ない。その中で、梅干野・塩月・林 $(1990)^{1)}$ は、熱電対を用いて空ガラスの表面温度測定を行う場合の誤差要 因を分類整理するとともに、屋外における予備実験および実験室 実験より測定誤差を定量化している。すなわち、(1) 熱電対を透明 ガラス、またはスリガラスに透明接着剤で接着する場合は、貼布面 に関係なくハンダ被覆された線径 $50 \mu \mathrm{m}$ 以下の熱電対を用いること により、約 $0.3^{\circ} \mathrm{C}$ 以内の精度で測定できること、(2) 熱電対をテープ で貼布する場合は、透明テープ、アルミ䈃テープ、白色ビニルテー プのうち、透明テープの測定誤差が最も小さく、テープの幅を $5 \mathrm{~mm}$ 以下にすることによって、 $0.5^{\circ} \mathrm{C}$ 以内の精度で測定できること(ただ し線径 $50 \mu \mathrm{m}$ 以下が条件)などを明らかにしている。

渡部・武田 $(1991)^{2)}$ は、非接触式表面温度測定方法には放射 の影響の把握に問題があるとして除外し、接触式表面温度測定方 法として、測温体装着後も測温体表面の放射熱収支特性や対流 熱伝達特性が周囲の透明板ガラスと同様になる方法を考案してい る。すなわち、素線径 $25 \mu \mathrm{m} \phi$ 以下の無処理熱電対をシアノアクリレ 一下系無色透明接着剤(低粘性型)を用い、公称厚さ $50 \sim 75 \mu \mathrm{m}$ の カバーガラス $(30 \mathrm{~mm} \times 30 \mathrm{~mm})$ で被覆接着したものである。これに
より、測温体表面と周囲の透明板ガラス表面との間には、日射量 $600 \mathrm{kcal} / \mathrm{m}^{2} \mathrm{~h}$ 前後のもと、放射温度計の最小検知温度差が $0.025^{\circ} \mathrm{C}$ の水準においても、放射温度画像上の差異は認められなかった、 としている。

しかし、これらの二法は、高い精度を要求するあまり、実用性に 乏しい面がある。たとえば、使用されている線径 $50 \mu \mathrm{m}$ 以下の極細 の熱電対は細すぎて取り扱いに特別な注意を要するため、一般に 行われる現場での多項目が必要な熱環境測定には応用しがたい ことが挙げられる。

そこで本論文では、通常の現場測定において実行可能な、日射 が当たったガラス板の表面温度を定める方法を提示し、その有効 性を実験により検討する。方法の基本は、通常用いる熱電対でガ ラス板の表面温度と、別に日射量を測り、温度と日射量の回帰式を 基に補正することによって、ガラス板の真の表面温度を定めるとい うものである。

\section{2. 表面温度測定の表式の導出}

図1は、水平に置かれたガラス板に日射が当たる場合のガラス表 面における熱収支関連項目を示している。ここで、ガラス板表面の 熱電対の温接点に対する熱平衡式は、

\footnotetext{
* 熊本県立大学環境共生学部居住環境学専攻 教授·工博

** 北九州市立大学国際環境工学部環境空間デザイン学科 $\mathrm{EA} \cdot$ 博士 (工学)

*** 秼)野田市電子環境分析事業部 修士(工学)
}

Prof., Division of Human Habitat, Faculty of Environmental and Symbiotic Sciences, Prefectural University of Kumamoto, Dr. Eng.

Engineering Advisor, Department of Environmental Space Design, Faculty of Environmental Engineering, The University of Kitakyushu, Dr. Eng. Nodaichi Electronics Company, Environmental Analysis Bureau, M. Eng. 


$$
a_{t} \cdot J=\alpha_{r: t}\left(T_{t}-T_{r}\right)+\alpha_{c}\left(T_{t}-T_{a}\right)+(1 / r)\left(T_{t}-T_{b}\right)
$$

で示され、ガラス板表面温 $T_{\mathrm{g}}$ を測る位置における熱平衡式は、

$$
a_{g} \cdot J=\alpha_{r, g}\left(T_{g}-T_{r}\right)+\alpha_{c}\left(T_{g}-T_{a}\right)+(1 / r)\left(T_{g}-T_{b}\right)
$$

で表される。

$$
\text { ここに、 }
$$

$a_{\imath} ：$ 透明テープ表面の日射吸収率 [ND]

$a_{g}:$ ガラス板表面の日射吸収率 [ND]

$J$ : ガラス板表面に入射する日射量 $\left[\mathrm{W} / \mathrm{m}^{2}\right]$

$\alpha_{r l}:$ 透明テープ表面の放射熱伝達率 $\left[\mathrm{W} / \mathrm{m}^{2} \mathrm{~K}\right]$

$\alpha_{r: g}:$ ガラス板表面の放射熱伝達率 $\left[\mathrm{W} / \mathrm{m}^{2} \mathrm{~K}\right]$

$\alpha_{c}$ : ガラス板表面の対流熱伝達率 $\left[\mathrm{W} / \mathrm{m}^{2} \mathrm{~K}\right]$

$r:$ ガラス板の伝導熱抵抗 $\left[\mathrm{m}^{2} \mathrm{~K} / \mathrm{W}\right]$

$T_{i}$ : 熱電対の指示する温度 $[\mathrm{K}]$

$T_{g}:$ ガラス板の表面温度 $[\mathrm{K}]$

$T_{r}$ : ガラス板表面から見た周辺の放射温度 $[\mathrm{K}]$

$T_{a}:$ 周辺の気温 $[\mathrm{K}]$

$T_{b}$ : ガラス板背面の温度 $[\mathrm{K}]$

である。 $T_{t}$ と $T_{g}$ の測定点は互いに近くに位置させるため、式(1)、

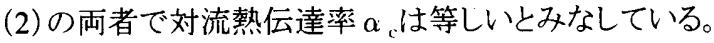

式(2)から式(1)を差し引き、変形して整理すると、ガラス板の表 面温度について、次の式(3)が得られる。

$$
T_{g}-T_{r}=\frac{\left(a_{g}-a_{t}\right) J-\left(\alpha_{r, g}-\alpha_{r, t}\right)\left(T_{1}-T_{r}\right)}{\alpha_{r, g}+\alpha_{c}+(1 / r)}
$$

ここで、放射熱伝達率を温度係数 ${ }^{3} \kappa を$ 用いて表すと、

$$
\begin{aligned}
& \alpha_{r, g}=\varepsilon_{g} \kappa_{g} \\
& \alpha_{r, l}=\varepsilon_{t} \kappa_{\prime}
\end{aligned}
$$

となる。 $\varepsilon g$.はガラス板表面の放射率[ND]、 $\varepsilon$ ，は透明テープ表面 の放射率[ND]である。また、近似的には $T_{g}=T ，$ であるから、 $\kappa_{g}=$ К，とおくことができる。

分子第2項の温度差 $\left(T_{1}-T_{r}\right)$ について、 $T_{r}$ は天候が大きく変 わらない限り、定数とおいて差し支えない。 $T$ （は測定によって得ら れるが、熱電対で測った表面温度 $T$ ，は日射量 $J に$ 応じて比例的 に変わると考えられるので、定数p、qを用いて

$$
T_{1}=\mathrm{p} \cdot J+\mathrm{q}
$$

と表す。

式(6)を式(3)に代入して以上をまとめると、定数 A、B を用いて 式(3)は、

$$
T_{g}-T_{1}=\mathrm{A} \cdot J+\mathrm{B}
$$

で表されることになる。こに、

$$
\begin{aligned}
& \mathrm{A}=\frac{\left(a_{g}-a_{t}\right)-\left(\varepsilon_{g}-\varepsilon_{t}\right) \kappa_{t} \cdot \mathrm{p}}{\varepsilon_{g} \kappa_{t}+\alpha_{\mathrm{c}}+(1 / r)} \\
& \mathrm{B}=\frac{-\left(\varepsilon_{g}-\varepsilon_{t}\right) \kappa_{t}\left(\mathrm{q}-T_{r}\right)}{\varepsilon_{g} \kappa_{t}+\alpha_{\mathrm{c}}+(1 / r)}
\end{aligned}
$$

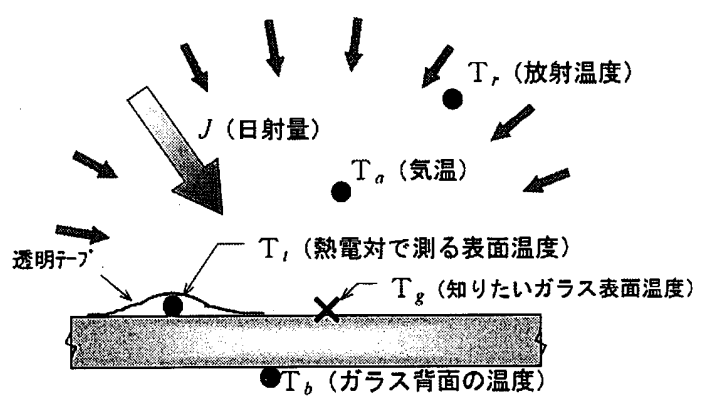

図 1 ガラス板表面の熱収支関連項目

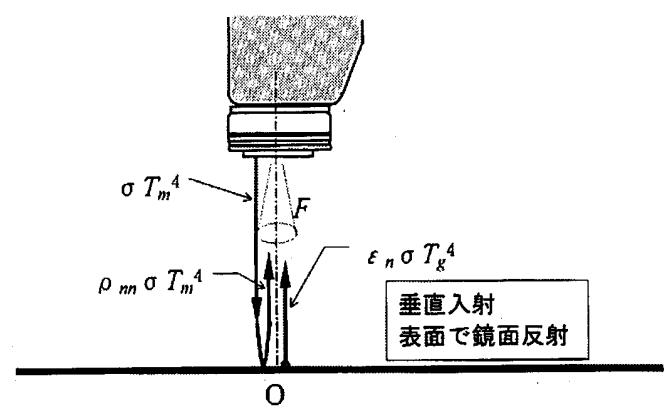

図 2 熱画像式放射温度計の対物レンズを通して 入射する、熱放射の状況の説明図

である。

$\mathrm{A} 、 \mathrm{~B}$ の值については、 $T_{g} 、 T 、 J$ の実験値をもとに直線回帰式 を求めて決定する。 $T_{g}$ は熱画像式の放射温度計で測定される。

A、B が求まれば、日射が当たるガラス板表面温度 $T_{g}$ は熱電対 を用いて測定された表面温度值 $T$ ，と測定された日射量をを用いて

$$
T_{g}=T_{1}+\mathrm{A} \cdot J+\mathrm{B}
$$

で求められる。即ち式(10)が日射量を用いたガラス板表面温度の 表式である。

\section{3. 実験に基づく回帰式の決定 \\ 3.1 実験方法}

(1) ガラス板表面温度の測定装置

ガラス板を水平に保持して日射を当て、ガラス板に垂直に、ガラ ス板の断面内に熱流が生じるようにするため、厚さ $6 \mathrm{~mm}$ 、辺々 900 $\times 900 \mathrm{~mm}$ の透明板ガラスを、内法 $300 \times 800 \times 800 \mathrm{~mm}$ 、外寸 400 $\times 1000 \times 1000 \mathrm{~mm}$ の断熱材でできた、上面だけが開放した箱に乗 せ、天空率の大きい建物屋上に設置した。箱の内面は黒色の紙貼 りで、日射が当たった状態ではガラス板を透過した日射熱により箱 内は高温になる。そのためガラス面を通じての伝導による熱流の向 きは一般に上向きとなる。

\section{（2）接触型の表面温度測定}

接触型の表面温度測定には次の3種類の熱電対を用いた。

\section{(a) 極細E型熱電対}

直径 $0.076 \mathrm{~mm}$ の極細E型熱電対(クロメル・コンスタンタン)の点 溶接された温接点をガラス板表面に接触させ、上から厚さ $0.055 \mathrm{~mm}$ のOPP(ボリプロピレン)透明テープを貼って、極細熱電 

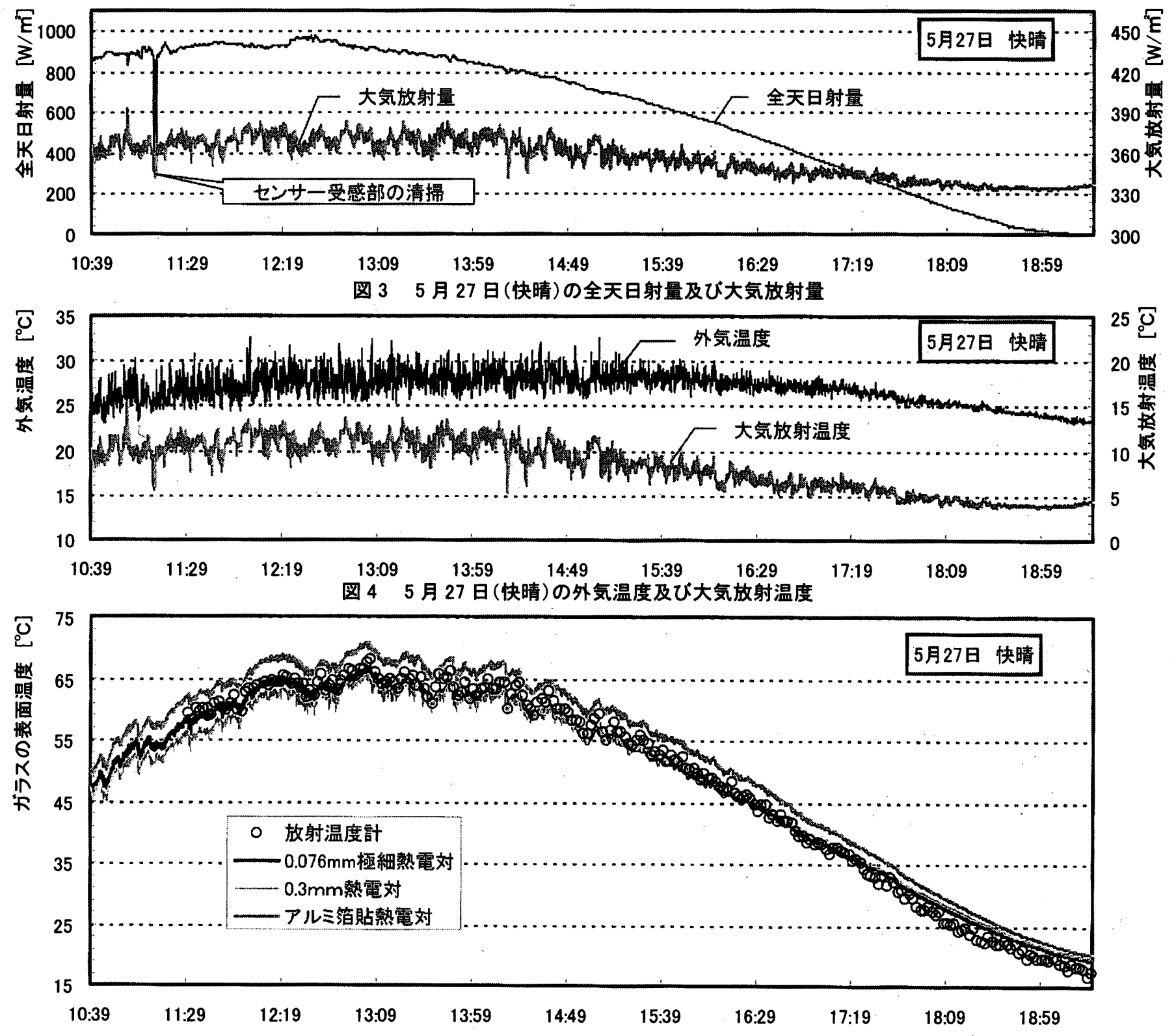

図 55 月 27 日(快晴)のガラス表面温度

対が動かないように固定した。一般に多用されているT型熱電対で は、銅線が細くて切れやすく、作業性が劣るので、それを避けるた めにE型を用いた。測定場所は1ケ所のみである。

\section{(b) $0.3 \mathrm{mmT}$ 型熱電対}

建築環境工学分野の測定で常用される直径 $0.3 \mathrm{~mm}$ のT型熱電 対を用いた。透明テープによる固定の仕方は、極細熱電対の場合 と同様である。測定場所による測定值の違いが無いことを確認する ために、測定場所を 2 力所選び、それぞれ独立に測定を行った。

（c）アルミ箔テープ貼り熱電対

透明テープに代わって、一般の熱工学測定で推奨されるアルミ 箔テープで熱電対の温接点を固定するものを、一点だけ設置した。 熱電対は直径 $0.3 \mathrm{~mm}$ のT型熱電対である。

(3) 非接触型の表面温度測定

非接触型の表面温度測定には表面の放射率補正機能付きの 熱画像放射温度計 (サーマルビデオシステムTVS-600(株) 日本ア ビオニクス、センサーの波長感度 8〜14 $\mu \mathrm{m}$ ) を用いた。
ガラス板上の測定点から見える周囲の放射温度 $T_{r}$ が天空の大 気温度ではなく、放射温度計そのものの温度を測定するように配 置を定める。図 2 に示す配置がそれで、放射温度計のレンズの光 軸がガラス板表面に対して、垂直になるように配置する。

ガラス板表面の垂直 (法線) 方向の放射率を $\varepsilon$ 川垂直方向の鏡 面反射率を $\rho_{m}$, 、垂直方向の環境温度、即ちレンズの温度 (正しく はレンズから測定点に向かう放射温度)を $T_{m}$ とすると、光軸に沿っ てレンズに入る放射量 $\sigma T_{0}^{4}$ は、

$$
F \sigma T_{0}^{+}=F\left(\varepsilon_{n} \sigma T_{g}^{4}+\rho_{m} \sigma T_{m}^{4}\right)
$$

であるから、 $T_{g}$ は次に示す式(12)で表される。

$$
\sigma T_{g}^{4}=\frac{\sigma T_{0}^{+}-\left(1-\varepsilon_{n}\right) \sigma T_{m}^{4}}{\varepsilon_{n}}
$$

ここに F はレンズの視野に対応した形態係数である。式(12)に おいて、放射率 $\varepsilon$ n及び $T_{m}$ を予め指定する必要があるが、 $\varepsilon$ „は力 


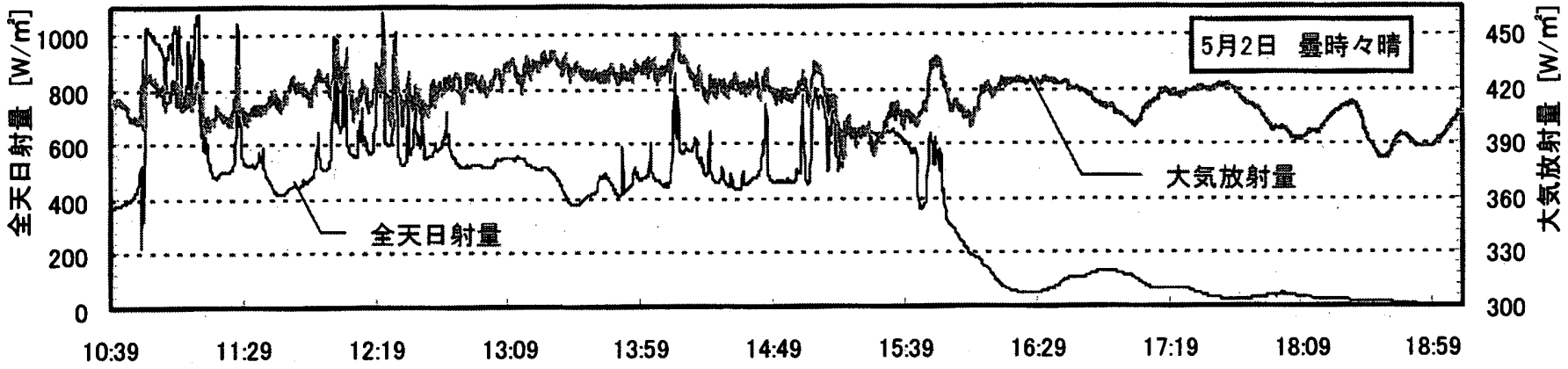

图 65 月 2 日(量時々晴)の全天日射量及び大気放射量

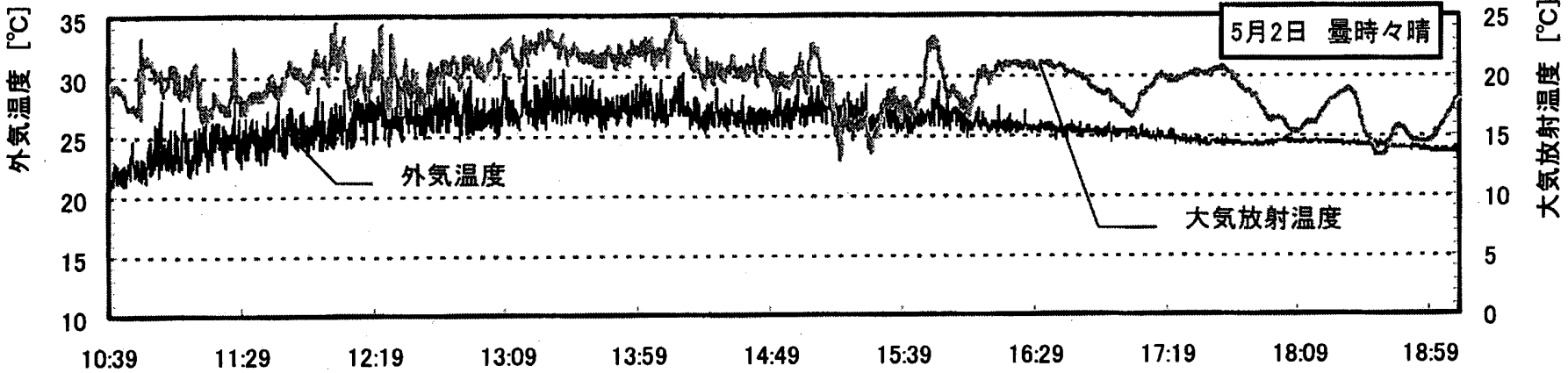

图 75 月 2 日(量時々晴)の外気温度及び大気放射温度

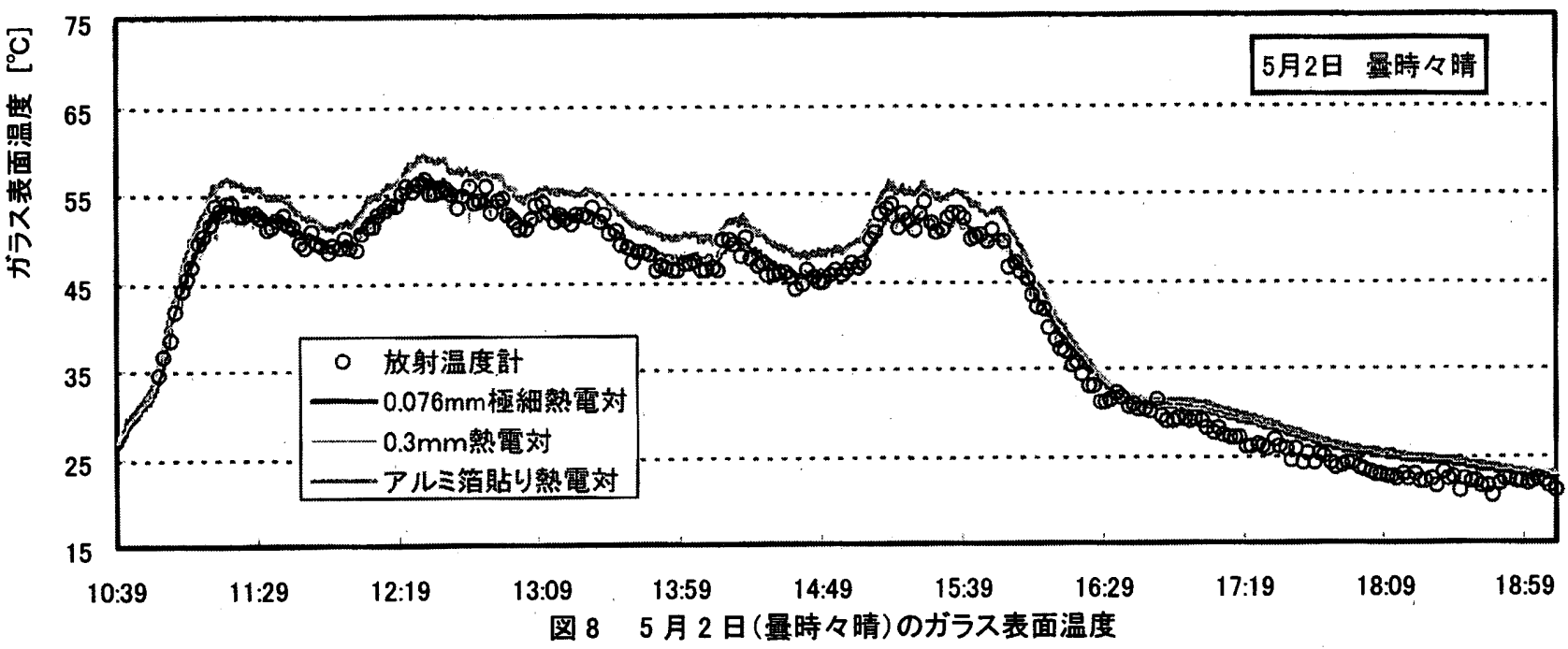

タログにある透明板ガラスの値"゙を利用でき、また本実験で用いた 放射温度計は計器内部の温度を測定しているため、 $T_{m}$ として近似 的にその值を利用できる。式 (12)に関するこれらの補正は計器内 部で行われ、従つて正確なガラス板の表面温度 $T_{g}$ が得られる。

\section{(4) 関連気象要素の測定と記録方法}

表面温度の測定のほかに、関連する気象要素として周辺の気温、 水平面全天日射量、水平面全天放射量及び周辺風速の測定を行 った。

気温の測定には直径 $0.076 \mathrm{~mm}$ のE型熱電対を用いた[ik.tit 门]。

水平面全天日射量の測定には精密全天日射計(英弘精機偐)、 MS-801), 水平面全天放射量の測定には精密赤外放射計 (英弘 精機(侏)、MS-202）を用いた。風速の測定には超音波三次元風速 計(森カイジョー)を用いた。

接触型表面温度のほか、気温、全天日射量、全天放射量及び 風速は、そのすべてをデータロガー(江藤電気侏、サーモダック $\mathrm{EF})$ に接続し、10 秒間隔で記録した。制御する時計は、標準時表
示時計に同期させた。

熱画像式放射温度計による非接触型表面温度測定は、標淮時 表示時計に基づいた 2 分間隔で読み取り、記録した。

\section{2 実験結果}

\section{（1）快晴の実験}

2002 年 5 月 27 日に行った。南中は 12 時 14 分であり、このとき の太陽高度は 78.4 度である。天候は北方あるいは東方にわずか に雲が認められる程度で、ほとんど快晴であった。

図3に、全天日射量と大気放射量を示す。大気放射量は絶対零 度基準で表示している。11 時 10 分頃に急激に值が低下している のは、センサー受感部の清掃作業の影響である。12 時 10 分前後 に日射量がわずかに低下しているのは、太陽を含む周辺に薄い雲 が生じたことの影響である。日射量、大気放射量及び放射温度の

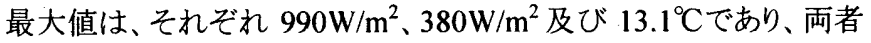
ともに、総じてなめらかな変化を示している。

図 4 に、測定機器付近の外気温度と大気放射量を摄氏温度に 

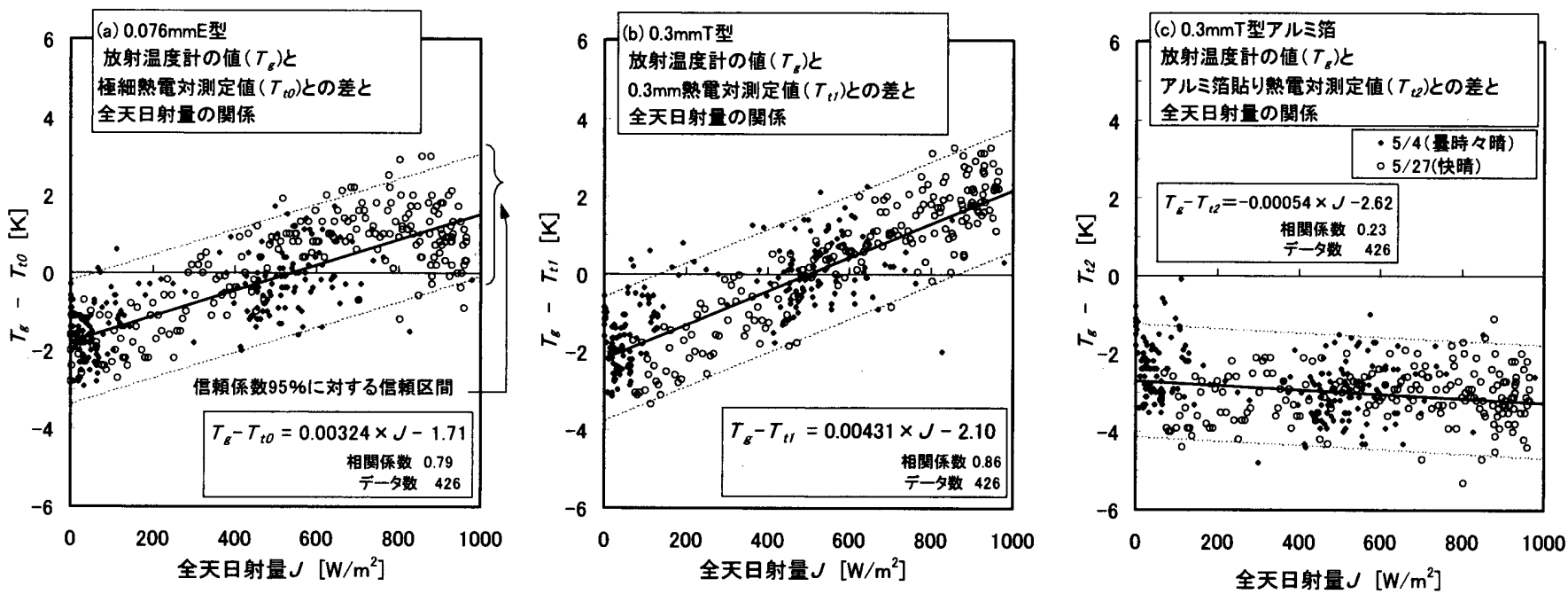

図 9 熱画像式放射温度計の読み取り值と熱電対の測定値との差 $(T g-T t)$ と水平面全天日射量 (Jとの回帰分析

換算して示す。外気温度と大気放射温度には $15 \mathrm{~K}$ 以上の差がある ことがわかる。大気放射温度の変化が、外気温度の変化とではなく 日射量の変化と同期しているように見えるが、これは日射によって 大気がわずかながらも吸収することから予想される現象である。風 速は 10 分間平均值で $0.7 \sim 1.6 \mathrm{~m} / \mathrm{s}$ であった。

図 5 にガラス板の表面温度を示す。直径 $0.3 \mathrm{~mm}$ 熱電対による 2 ケ所の測定值の差は最大でも $1 \mathrm{~K}$ であったから、両者の違いは無 視できるとみなして 2 ヶ所の平均值を示した。図から明らかなように、 アルミ箔貼り熱電対の測定値が常に最も高く、放射温度計の测定 值は、日中は直径 $0.3 \mathrm{~mm}$ 熱電対とアルミ箔貼り熱電対の間の值と なり、夕刻には最低の值になっているのが特徵である。

\section{（2）曇時々晴の実験}

2002 年 5 月 2 日に行った。南中は 12 時 14 分であり、このときの 太陽高度は 72.5 度である。天候は 16 時 30 分頃までは晴れたり量 ったりであったが、それ以降は量天となった。

図 6 に、全天日射量と大気放射量を示す。16 時 00 分頃までは 日射量が大きく変動しているのがわかる。大気放射量の変動は日 射量ほど大きくない。

図 7 に、外気温度と大気放射温度を示す。比較的滑らかな外気 温度の変動に対して、大気放射量は天気の変化に応じて変動が 見られる。外気温度と大気放射温度の差は、大気放射温度の影響 を受けて、5〜14K に変動した。風速は 10 分間平均值で、0〜 $1.5 \mathrm{~m} / \mathrm{s}$ であった。

図 8 に、ガラス板の表面温度を示す。16 時 00 分頃までは、天気 の変化を受け、日射量にともなって大きく変動している。これは日 射がガラス板だけでなく、背後の断熱箱内表面に当たって断熱箱 内部の気温を上げ、両方の温度上昇の効果が加算するためであ る。温度の表示については、前述の快晴の場合と同様の特徵が見 られる。

\section{3 相関関係}

\section{（1）表面温度の温度差と気象要素との相関関係}

本実験では熱画像式放射温度計による測定値を真值とみなし ている。正しいとみなすことの合理性については、後述する。

熱画像式放射温度計の読み取り值と熱電対の測定値との差 $\left(T_{g}\right.$
$\left.-T_{t}\right)$ に着目し、それと水平面全天日射量との相関性を調べる。図 9(a) は直径 0.076mm 極細熱電対を用いた場合、図 9(b) は直径 $0.3 \mathrm{~mm}$ 熱電対を用いた場合、図 $9(\mathrm{c})$ はアルミ箔貼り熱電対を用い た場合の相関を示す。いずれの図も○印は快晴、○印は曇時々 晴の実験結果を示している。太陽高度が最高となる時刻から日射 量が 0 以下になるまでの時間を解析の対象とし、2 分毎の連続した 記録値である。

紙面の都合上ここに示さないが、 $\left(T_{g}-T\right)$ と大気放射量とは相関 性が無いことを示した。

同じく風速と $\left(T_{g}-T_{t}\right)$ との相関関係を図示すると、天候による違 いは認められなかったが、分布形状が棈円形を示し、ゆるい相関 性が認められた。

\section{（2）表面温度の温度差の回帰式}

快晴 (5 月 27 日) と曇時々晴 (5月 2 日)の両日について、太陽 高度が最高となる時刻から日射量が 0 以下になるまでの、合計 426 個のデータを用いて、線形回帰分析で得られた結果は次の通りで ある。

（a）直径 $0.076 \mathrm{~mm}$ 極細E型熱電対に透明テープを貼った場合

$$
T_{g}-T_{t 0}=0.00324 \cdot J-1.71 \quad \text { 相関係数 }=0.79
$$

（b）直径 $0.3 \mathrm{~mm} \mathrm{~T}$ 型熱電対に透明テープを貼った場合

$$
T_{g}-T_{t 1}=0.00431 \cdot J-2.10 \quad \text { 相関係数 }=0.86
$$

（c）アルミ箔貼り $0.3 \mathrm{~mm} \mathrm{~T}$ 型熱電対を用いた場合

$$
T_{g}-T_{t 2}=-0.00054 \cdot J-2.62 \quad \text { 相関係数 }=0.23
$$

これらの結果から、相関関係を利用するには、(1)アルミ箔を貼つ た場合は不適当、(2)透明テープを貼った場合は通常よく用いられ る直径 $0.3 \mathrm{~mm}$ T型熱電対で充分である、ことがわかる。

\section{4. 回㛿式の合理性の検討}

実験で得られた回帰式の合理性について、測定で得られた各種 事項の生起の合理性を検討し、さらに理論式における各種係数の 取り得る数值の検討を行って、回帰式の合理性の検証とする。各 
種の検証が矛盾なく行われた ならば、当初設定したように、 熱画像式放射温度計による表 面温度測定は正しく行われた ことを意味し、得られた回帰式 も正しいものと認めることがで きる。

\section{1 熱画像測定結果に基づく 合理性の検討}

写真 1 に、ガラス板の表面 温度測定における装置の配 置状況を示す。11 時 30 分から 日没までは全て熱電対の温接 点に太陽の直射が当たるよう に配置を調整した。熱画像式

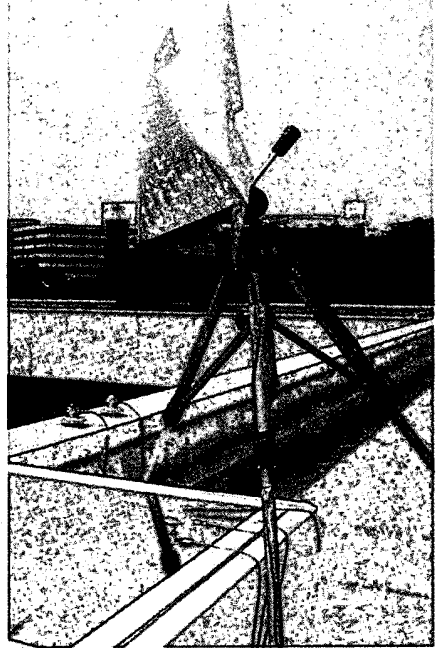

写真 1 装置の配置状況 放射温度計はアルミ箔付き断熱材で覆うことによって、日射熱吸収 による高温化を防いだ。この際、アルミ箔面で反射した太陽光がガ ラス面上の温度センサーに当たらないように注意した。

写真 2 は、熱電対の温接点の配置状況を示す。記号 A は極細 熱電対、 $\mathrm{B} 1$ 及び $\mathrm{B} 2$ は直径 $0.3 \mathrm{~mm}$ 熱電対、 $\mathrm{C}$ はアルミ䈃貼り熱電 対である。熱画像式放射温度計による測定点は、A、B2 及び C で 囲まれたガラス部分の中心点になるように、測器を固定した。

写真 3 は、日射が当たった状態で、 5 月 20 日の 13 時 15 分に放 射温度計が示した熱画像である。写真 2 と異なって熱電対の温接 点を固定するテープの存在が明瞭に現れている。

\section{(1) 透明テープだけを貼った面に対する検討}

写真 3 の赤系統の色に注目すると、色の違いによって透明テー プの形状を見てとれる。透明テープの見かけの表面温度は、周辺 の赤色より白っぽいことから、ガラス板の見かけの表面温度より高 いことを示している。

赤地の部分には透明テープ以外にも白っぽい部分が見られる。 これは覆いつきの放射温度計と支持する三脚の影であり、それ以 外のほぼ同色の濃い赤色は温度の低い大気放射を映しているも のである。

透明テープの色はどの場所も同様に白っぽい赤色を示している。 このことから、透明テープ表面は鏡面反射性ではなく拡散反射性 を示すとみなし、したがって、次のように、表面で反射するのは大 気放射のみである、とみなす。

すなわち、透明テープの見かけの温度を $T_{v m}[\mathrm{~K}]$ とすると、

$$
T_{v m}=\left[\varepsilon_{v} T_{g v}^{4}+\left(1-\varepsilon_{v}\right) T_{r}^{4}\right]^{1 / 4}
$$

と表される。

ここに $\varepsilon_{v}:$ ガラス板上に密着した透明テープの放射率[ND]、

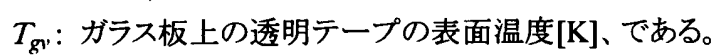

一方、ガラス板表面の見かけの温度を $T_{g m}[\mathrm{~K}]$ とすると、

$$
T_{g m}=\left[\varepsilon_{g} T_{g}^{4}+\left(1-\varepsilon_{g}\right) T_{r}^{4}\right]^{1 / 4}
$$

と表される。

ここに $\varepsilon_{g}:$ ガラス板表面の放射率[ND]、 $T_{\mathrm{g}}$ : ガラス板表面の温 度[K]、である。

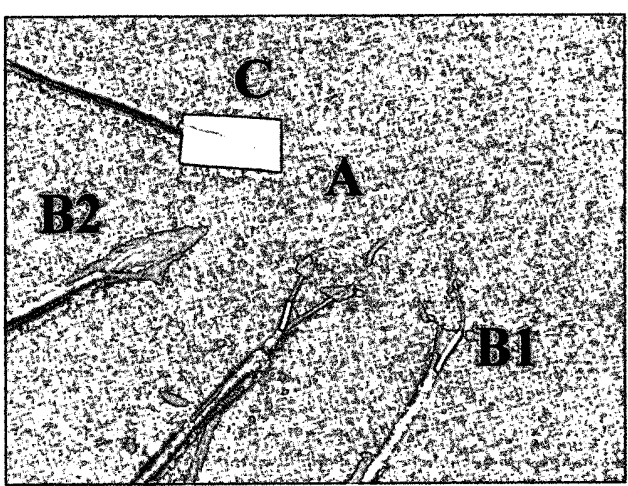

\section{写真 2 熱電対の温接点の配置状況}

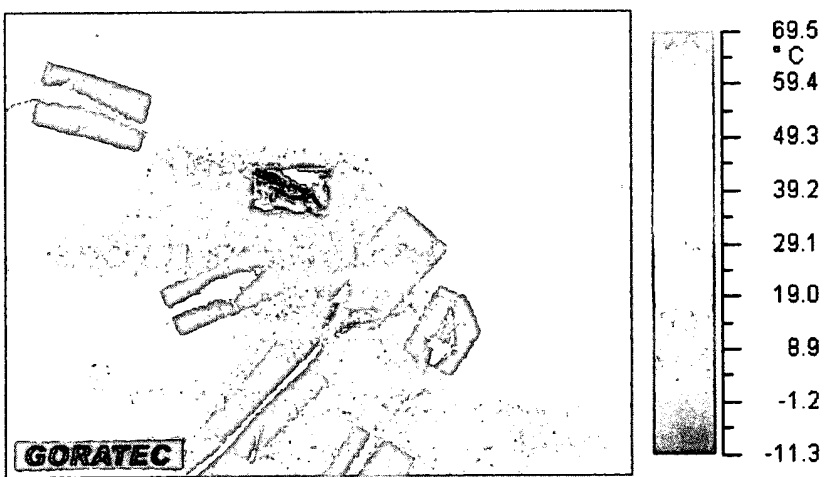

写真 3 熱画像 (5 月 20 日 13 時 15 分)

カタログ4) により $\varepsilon_{g}=0.89$ と与えられているから、13 時 7 分のガ ラス板表面温度 $67^{\circ} \mathrm{C} 、 大$ 気放射温度 $11^{\circ} \mathrm{C}$ を用いると、ガラスの見 かけの表面温度 $62^{\circ} \mathrm{C}$ が得られる。

透明テープを貼った部分の 13 時 7 分の值は、透明テープの厚さ が薄いため、透明テープの表面温度 $\left(T_{g v}\right)$ とガラス板の表面温度 $\left(T_{g}\right)$ が等しい $\left(T_{g v}=T_{g}\right)$ とみなすと、透明テープ上の見かけの表 面温度 $T_{v m}$ がガラス板の見かけの表面温度より高いことから、 $\varepsilon_{v}>$ $\varepsilon_{g}=0.89$ でなければならないことになる。このように、ガラス板上 に透明テープを貼った状態での放射率はガラス板そのものの放射 率より大きいことがわかる。

\section{（2）熱電対素線に透明テープを貼つた面に対する検討}

写真 3 を見ると、透明テープ下の熱電対素線 (外側被覆と絶縁 被覆の両者とも、はがしてむきだしになった金属線)の色はテープ 面より濃いが、裸線(外側被覆のみはがし、絶縁被覆はついたまま の線)の部分ほど濃くはない。見かけの温度も熱電対素線上の透 明テープは、透明テープだけの部分と裸線部分の中間にある。極 細熱電対と直径 $0.3 \mathrm{~mm}$ 熱電対の違いは判然としない。

熱電対素線上の透明テープの見かけの表面温度を $T_{x m}[\mathrm{~K}]$ とす ると、

$$
T_{x m}=\left[\varepsilon_{x} T_{g x}^{4}+\left(1-\varepsilon_{x}\right) T_{r}^{4}\right]^{1 / 4}
$$

と表せる。こに $\varepsilon_{x}$ : 熱電対素線上に貼った透明テープの放射率

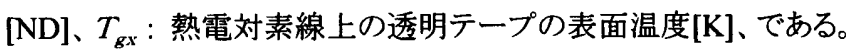

一方、放射温度計から見た視野の中心に位置するガラス板の見 かけの表面温度を $T_{c m}[\mathrm{~K}]$ とすると、

$$
T_{c m}=\left[\varepsilon_{g} T_{g}^{4}+\left(1-\varepsilon_{g}\right) T_{m}^{4}\right]^{1 / 4}
$$


と表せる。ここに $\varepsilon_{\mathrm{g}}=0.89 、 13$ 時 7 分のガラス板表面温度は $67^{\circ} \mathrm{C}$ であり、 $T_{m}$ は放射温度計本体の温度であるから、仮に $T_{m}=273+30$ とおくと、放射温度計から見た視野の中心のガラス板の見かけの表 面温度 $T_{c m}$ は $63^{\circ} \mathrm{C}$ となる。先に求めたガラスの見かけの表面温度 $62^{\circ} \mathrm{C}$ よわずかに高い。

写真 3 を見ると、熱電対素線上に透明テープを貼った見かけの 表面温度 $T_{x m}$ は放射温度計から見た視野中心のガラス板の見かけ の表面温度 $T_{c m}$ より若干低く見えるので、

$$
T_{x m}<T_{c m}
$$

となるはずである。

ここで、仮に $\varepsilon_{x}=0.8$ とおくと、熱電対素線上の透明テープの見 かけの表面温度 $T_{x m}$ は $58^{\circ} \mathrm{C}$ となり、色温度指標より妥当な值である ことがわかる。換言すれば、熱電対素線の透明テープを貼ったとこ ろの放射率は、ガラスの上に透明テープを貼ったところの放射率よ り小さい。これは、透明テープの厚さが薄いために、下地材料の放 射率の違い、即ち熱電対素線の放射率がガラスの放射率より小さ いことの効果が、透明テープの表面にも影響を及ぼしたものと考え られる。

\section{2 回帰式の係数に関する合理性の検討}

測定值に基づいて、 $y$ の期待值 $E(y)$ について、次の単回帰式 を導くことができた。

$$
E(y)=\beta_{0}+\beta_{1} \cdot x
$$

ここに、 $y$ : ガラス板の表面温度差 $\left(=T_{g}-T_{1}\right) 、 x$ : 水平面全 天日射量 $\left(=\right.$ )、である。また切片 $\beta_{0}$ は式(9)で表される内容をも ち、回帰係数 $\beta_{1}$ は式(8) で表される内容を持つ。

以下にこれらの值の合理性について検討する。

(1) 切片 $\beta_{0}$ に対する検討

$$
\beta_{0}=\frac{-\left(\varepsilon_{g}-\varepsilon_{t}\right) \kappa_{t}\left(\mathrm{q}-T_{r}\right)}{\varepsilon_{g} \kappa_{t}+\alpha_{c}+(1 / r)}
$$

式(5)で示したように、ย，は透明テープ表面の放射率であるが、 これには、アルミ箔を貼った面の放射率 $\varepsilon p$ と、熱電対素線に透明 テープを貼つた面の放射率 $\varepsilon$, の両者がある。

極細E型熱電対の単回帰式 (図 $9(\mathrm{a})$ )、直径 $0.3 \mathrm{~mm}$ T型熱電対 の单回帰式(図.9(b))、及びアルミ箔貼り熱電対の単回帰式(図 9 (c))を見ると、いずれも切片 $\beta_{0}$ は負の值である。これについて式 (22)を用いて検討する。

式(22)の分母は、常に正である。分子では、К，が常に正である。 q については式(7)を変形すると、

$$
T_{t}=-\mathrm{A} \cdot J+T_{g}-\mathrm{B}
$$

であるから、 $\left(T_{g}-\mathrm{B}\right)$ が $\mathrm{q}$ に相当する。 $\mathrm{B}=\beta_{0}$ であり、極細 $\mathrm{E}$ 型熱 電対で 1.71 、直径 $0.3 \mathrm{~mm}$ T型熱電対で 2.10 、アルミ箔貼り熱電対 で2.62である。例えば、 $T_{g}$ の值は、快晴日の 13 時 7 分で $67^{\circ} \mathrm{C} 、 19$ 時 0 分で $19.5^{\circ} \mathrm{C}$ である。したがって $\left(T_{g}-\mathrm{B}\right)$ は最小でも $64^{\circ} \mathrm{C}$ $17^{\circ} \mathrm{C}$ で正であり、qは負になることはない。

一方、大気放射温度 $T_{r}$ の值は快晴の 13 時 7 分のとき $11^{\circ} \mathrm{C} 、 19$ 時 0 分のとき $4.3^{\circ} \mathrm{C}$ であるから、 $\left(q-T_{r}\right)$ は $53^{\circ} \mathrm{C}$ か $13^{\circ} \mathrm{C}$ で正であり、
$\left(\mathrm{q}-T_{r}\right)$ は負になることない。

分子の $\left(\varepsilon_{g}-\varepsilon_{t}\right)$ については、カタログ4)より $\varepsilon_{g}=0.89$ と定め、 他の放射率については $\varepsilon_{p}=0.2 、 \varepsilon_{x}=0.8$ と仮定した。これに対し ては、 $\left(\varepsilon_{g}-\varepsilon_{i}\right)$ は常に正とみることができる。

したがって、 $\beta_{0}$ は負の值をとることになる。以上、 $\beta_{0}$ が負である ことの合理性が説明できた。

\section{(2) 回螮係数 $\beta_{1}$ に対する検討}

$$
\beta_{1}=\frac{\left(a_{g}-a_{t}\right)-\left(\varepsilon_{g}-\varepsilon_{t}\right) \kappa_{t} \cdot \mathrm{p}}{\varepsilon_{g} \kappa_{t}+\alpha_{c}+(1 / r)}
$$

式(23)にしたがって、式(24) 中の $\mathrm{p}$ は (-A)に相当する。アルミ 箔を貼った場合では $\mathrm{A}=-0.00054$ であるから $\mathrm{p}$ は正である。極細 $\mathrm{E}$ 型熱電対及びT型熱電対 (直径 $0.3 \mathrm{~mm}$ )に透明テープを貼った場 合は、それぞれ $\mathrm{A}=0.00324 、 \mathrm{~A}=0.00431$ であるから $\mathrm{p}$ は負である。 したがって $\left(a_{g}-a_{1}\right)$ を除いた回帰係数 $\beta$ ，の符号は、アルミ䇴を貼 った場合は負、透明テープを貼った場合は正となる。

$a_{g}$ はガラス板表面の日射吸収率で、カタログ4より、厚さ $6 \mathrm{~mm}$ に 対して $a_{g}=0.12$ である。 $a$ ，については、まずアルミ箔表面に対して は、一般の金属では放射率 $\varepsilon p$ より日射吸収率は大きいことから、 $a_{t}=0.4$ (先述のように $\varepsilon_{p}=0.2$ と仮定した) と仮定すると、 $\left(a_{g}-a_{t}\right)$ は負となる。したがって、式(24)の右辺の両項ともに負であるから、 $\beta_{1}$ は負である。これは、統計的に求められた回帰倸数 $\beta_{1}$ の符号 と一致する。

熱電対の上に透明テープを貼った場合、透明テープは可視域 で透明性が高く、また厚さも薄いので、日射吸収率 $a$ ，は熱電対との 複合効果を示すはずである。熱電対は金属であり、アルミ䈃と類似 した性質を持つことは考えられるが、どのように複合効果が現れる かは不明である。しかし、放射温度計で測った見かけの表面温度 がともに若干低い温度を示したことから、温度上昇をもたらす日射 吸収は大きくなかったことが推測される。また、図 5 において、日中 の熱電対に透明テープを貼った表面温度が、熱画像放射温度計 で測った值より低く出ていることから、前者の日射吸収率 $a_{1}$ がガラ ス板の日射吸収率 $a_{g}$ より小さかったと推測される。いずれも $\left(a_{g}-\right.$ $\left.a_{1}\right)$ は正であったと推測される。したがって、 $\beta$ 、は正となる。

以上、回㷌係数 $\beta$ ，については、熱電対の上の透明テープを貼 った場合、アルミ箔を貼った場合ともに、常に回㷌式で得られた数 値の符号の合理性が説明できた。

\section{5. 垂直ガラス面への適用}

ガラス板表面温度の測定について、水平面に置かれたガラス板 を対象に検討してきたが、通常のガラス板は空面として使われるた め、垂直に位置している。したがって、本研究で提案した日射が当 たるガラス板表面温度の実用的測定法が、垂直なガラス板に対し て適用可能であるか、検討する必要がある。

水平面と垂直面の違いは、水平面では天空率 (天空を見る形態 係数)が大きいのに対して、垂直面では天空率が 0.5 以下となるこ とである。まず、日射に関しては、ガラス板面で測定を行う限り、面 が水平か垂直かに関係なく、日射の測定值をそのまま使用できる ので問題ない。一方、長波長放射については、大気の放射温度が 一般に地物より低温である。[3.2 実験結果]でも述べたが、気温と 
大気の放射温度との差は、調べた例では、快晴時で $15 \mathrm{~K}$ 、曇天時 で 5 14K であった。この温度差が、実は、式(10)の切片 B に相当 寸ると考えられるものである。 B の值は天空が開けた水平面に対し て決定された。したがって、垂直なガラス板面に対しては、ガラス板 面から見える天空率を切片 B に乗じることによって換算し、求める ことができる。

\section{6. まとめ}

（1）日射が当たるガラス板表面温度の実用的測定法として、通 常用いる直径 $0.3 \mathrm{~mm}$ T型熱電対を透明テープで貼って測定した ガラス板の表面温度と、そのときの日射量から、真のガラス板の表 面温度を求める方法を提案した。

（2）ガラス板表面温度を定める際に必要となる回帰式(求める ガラス板の表面温度と熱電対で測定した表面温度との温度差の、 日射量による単回帰式)を、快晴時及び薷時々晴の天候時の実験 結果より決定した。

（3）実験的に求められた回帰式の成立の合理性について、実 験及び理論の両面から検討を加え、矛盾なく説明できることを示し、 本論文で提案した方法の信頼性が高いことを確認した。

（4）提案した実用的測定法では、透明テープを用いて、直径

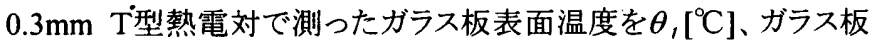
面に対する日射量を $J\left[\mathrm{~W} / \mathrm{m}^{2}\right]$ とすると、真のガラス板の表面温度 $\theta_{g}\left[{ }^{\circ} \mathrm{C}\right]$ は、

$$
\theta_{g}=\theta_{t}+0.00431 \cdot J-2.10 \cdot \phi
$$

で表される。ここで、 $\phi:$ ガラス板面から見た天空率[ND]で、ガラス 板面は水平面に限らず、垂直面や傾斜面でも適用できる。

[謝辞] 実測に際して、熊本県立大学環境共生学部居住環境学 専攻嘱託助手の中山みつこ氏、同 4 年生の緒方美里氏、山下佳 織氏の多大なる御協力を得た。心より謝意を表します。
[注記 1]

センサーの大きさを小さくすると、対流伝達に比して放射伝熱の効 果が減少して、測定値が可及的に気温に近づくという特性に基づ いている。文献5) に従えば、直径 $0.1 \mathrm{~mm}$ の熱電対の場合は、日射 量が $700 \mathrm{kcal} / \mathrm{m}^{2} \mathrm{~h}$ で風速 $0.2 \mathrm{~m} / \mathrm{s}$ では、気温測定における誤差は $0.6^{\circ} \mathrm{C}$ 以内、 $2 \mathrm{~m} / \mathrm{s}$ では $0.3^{\circ} \mathrm{C}$ 以内であった。

\section{[本稿に関連する既発表論文]}

本論文は、以下の発表論文に新たな研究結果を加えて修正した ものである。

[1]中村泰人、平川真由美、宮島教江: 日射が当たるガラス板の表 面温度測定法 その 1 測定法の提案、日本建築学会九州支部研 究報告第 41 号、pp.385-388、2002 年 3 月 [2]中村泰人: 日射が当たるガラス板の表面温度測定法、日本建築 学会大会学術講演梗概集 (北陸) 、pp.5-6、2002 年 8 月

\section{[参考文献]}

1）梅干野昆、塩月義隆、林宏幸: 日射透過材料の表面温度測定 法に関する実験的研究、日本建築学会計画系論文報告集、第 408 号、pp.13-21、1990.2

2) 渡部真志、武田仁: 短波長放射中のガラス表面温度測定方法 に関する実験的研究、日本建築学会計画系論文報告集、第 426 号、pp.25-37、1991.8

3) 前田敏男: 伝熱学、新訂建築学大系 8 、音・光・熱・空気・色、彰 国社、p.337、1969

4) 日本板硝子株式会社:ガラス建材総合カタログ、ガラス技術資料 編、1998 年 11 月

5) 中村泰人:建築環境設計における気温測定のための検討、日 本建築学会近畿支部研究報告集 (環境工学)、pp.57-60、昭和 52 年 5 月 